Genij Ortopedii. 2021. Vol. 27, no. 5. P. 584-586.

https://doi.org/10.18019/1028-4427-2021-27-5-584-586

Discussion article

\title{
Comment on article \\ "Aesthetic surgery of the lower limbs in current orthopedic practice"
}

\author{
Pavel N. Kulesh ${ }^{1}$, Leonid N. Solomin ${ }^{2,3 凶}$
}

${ }^{1}$ St. George the Great Martyr City Hospital, St. Petersburg, Russian Federation

${ }^{2}$ National Vreden Medical Research Centre of Traumatology and Orthopedics, Saint-Petersburg, Russian Federation ${ }^{3}$ St. Petersburg State University, Saint-Petersburg, Russian Federation

Corresponding author: Leonid N. Solomin, solomin.leonid@gmail.com

For citation: Kulesh P.N., Solomin L.N. Comment on article "Aesthetic surgery of the lower limbs in current orthopedic practice". Genij Ortopedii, 2021, vol. 27, no 5, pp. 584-586. https://doi.org/10.18019/1028-4427-2021-27-5-584-586

No doubt that the topic raised by the authors of the study under comment [1] is very relevant. It is probably primarily due to a very limited number of publications related to it. On the other hand, similar operations have been performed all over the world with the rationale for either "standard" orthopedic deformity correction, or the struggle for patient's beauty and psychological comfort, or the prevention of arthrosis. Therefore, we may repeat that to determine the place of aesthetic surgery of the lower extremities in modern orthopedics is a more than a timely task. And, as it seems to us, the polemical to a certain extent nature of the article allows us to dwell on some points.

Thus, several statements of the authors in the "Introduction" section, unfortunately, can hardly be considered confirmed by the facts in the course of their own study or literary sources cited. Such as "Bone deformity is absent in false curvature which is associated with the distribution of soft tissues." and "Change in the shape of the lower limb skeleton inevitably results in its function". The assertion of the authors in the same section that "appearance of the limb depends on the shape of its skeleton", unfortunately, was not supported by the cited facts or literary references. So, probably, it can hardly be stated that in all cases the size of the diameter of the thigh is determined by the "shape of its skeleton", and not by the development of muscles, and (or) subcutaneous fat. Skin color is also a component of the "appearance of the limb" and is certainly not determined by the "shape of the skeleton."

The assertion that "true curvature is associated with bone deformity" and is literally "varus deformity" and an indication for corrective osteotomy has been not supported by facts or literary references either. At the same time, there is a fairly extensive literature disproving it [2-7]. Moreover, one of the authors of the article in his earlier publication also stated that "in maintaining the anatomical axis of the limbs, passive non-closure of the knees up to $1.5-2 \mathrm{~cm}$ is possible, which is caused by the peculiarity of the distribution of soft tissues of the medial surface of the knee" ([8], p. 210). In the same publication, the author presents "a case of simultaneous correction of the axis and length of the femur and lower leg on one side (stage 1) and on the other (stage 2)" ([8], pp. 190-191). In the photograph of the patient after the completion of treatment ( 2 years after its start), the shape of the legs corresponds to the O-shaped curvature ([8], p. 191, Fig. 7.12).

It seems to us suitable to discuss whether it is possible to "determine the place of aesthetic surgery of the lower extremities in current orthopedics" basing on the experience of treating patients who underwent interventions only on the lower legs (osteotomy of the tibia in the upper third) for their varus deformities? Patients who underwent surgery on other segments of the lower extremities (femur and foot) were not included in the study. Patients with valgus of the tibia or its deformities in the sagittal plane were not included in the study either.

Noteworthy is that for 10 years (the study group included patients who underwent surgery in the last 15 years), the study of the mechanical axis deviation was carried out incorrectly, that is without axial load (see section "Materials and Methods"). This fact excludes the influence of the Joint Line Convergence Angle (JLCA) on the investigated parameter, that is Mechanical Axis Deviation (MAD) $[3,6,9]$. Thus, the study is just incorrect (inappropriate to the described methods [3, 6 , 9]), but not "alternative".

Unfortunately, the text of the article does not contain explanation in what form the authors present the statistical values. However, if we assume that in the form of $\mathrm{M} \pm \delta\left(\mathrm{M}=91^{\circ}, \delta=2^{\circ}\right.$, see the section "Results and Discussion", then with the standard Gaussian distribution, the incidence of valgus complication in patients who completed treatment might account for more than $50 \%$ (more than 123 operated segments) [10]. The confidence interval $(\mathrm{M} \pm 3 \delta)$ of the mechanical Medial Proximal Tibia Angle (mMPTA) after treatment was $85-97^{\circ}$, the normal range being $85-90^{\circ}[3-6,9]$. The average value (M) also does not correspond to the normal range (the results of statistical calculations presented here and below were performed in accordance with a special generally accepted methodology for processing the results and cannot be recognized as an opinion, an "alternative" of the authors' opinion [10]). 
Re-identification of the O-shaped legs with the deformity of the skeleton is found in the section "Materials and Methods" when formulating indications for performing surgical interventions: "the main indication for surgery was the so-called true O-shaped curvature (varus deformity) of the lower extremities." The correctness of the statement is refuted by the results of the study in the corresponding section: the value of mMPTA before treatment was $85 \pm 4^{\circ}$. That is, the average value (M) corresponds to the lower limit of the norm $\left(85^{\circ}\right)$. The confidence interval of the statistic value for the standard normal distribution was $73-97^{\circ}$ [10]. The incidence of Mmpta $<85^{\circ}$ corresponding to varus deformity is only $50 \%$ (!) of all operated segments, what corresponds to 123 operations out of 246 . Thus, it can be assumed that the diagnosis of varus deformity of the lower leg in the patients with O-shaped legs was not confirmed in $50 \%$ of cases [10].

Moreover, in approximately $6 \%$ [10] cases (16 segments), the mMPTA value is in the range 91$97^{\circ}$, what corresponds not to varus, but to valgus! At the same time, the MAD value before surgery $(15 \pm 7 \mathrm{~mm})$ relative normal values of $-3 \mathrm{~mm}-+3 \mathrm{~mm}$ [9]) indicates the presence of deformity in more than $90 \%$ of cases [10]. This fact can be explained by the presence of varus deformity of the femur, since, based on the data presented in the article, the study of the relationship between the reference lines of the femur was not carried out. In addition to this: when correcting deformities of the tibia bones in the frontal plane, the analysis of the mechanical lateral distal tibia angle (mLDTA) is mandatory, including to determine the level of the deformity apex and the optimal level of osteotomy (Center of Rotation of Angulation - CORA), which is confirmed by the literature data $[3-5,9,11]$.

Decree of the Government of the Russian Federation No. 565 on military medical examination, being "the only expert document for today", should probably be taken into account. However, the determining factor for the diagnosis of deformity is the analysis of the relationship between the reference lines [3, 9, 12]. And an unreasonable (in the absence of deformity) osteotomy or deformity correction, which resulted in a different type of deformity, can have not only negative medical consequences. "Exceptions" are known: for example, high tibial osteotomy [11, 13-16], reconstruction of the proximal femur according to Ilizarov-Kaplunov (Ilizarov pelvic support osteotomy) [3, 17-20]. However, these operations, which are based on "creation of deformities", are justified precisely by their therapeutic effect, for which they had been developed.

In fact, the "Conclusions" that finalize the article are a declaration of previously known facts and statements. The data obtained by the analysis of the materials and results of authors' own research were taken into account, perhaps only indirectly, which is hardly correct for original articles [1]. Nevertheless, the article in question is of undeniable value, since the results of the study confirm:

1) In patients with O-shaped legs according to A.A. Artemiev, the diagnosis of varus deformity of the lower leg was sufficiently substantiated only in $50 \%$ of cases (mMPTA before surgery $85 \pm 4^{\circ}$ relative the normal values of $\left.85-90^{\circ}[3-6,9]\right)$;

2) When the desired shape of the legs is achieved (in $96.7 \%$ of cases), there is a high probability (more than $50 \%$ ) of valgus (mMPTA after treatment is $91 \pm 2^{\circ}$ relative the normal values of $85-90^{\circ}[3-6,9]$ ).

In conclusion, we would like to thank the authors of the article for the opportunity to present comments on the topic of our concern. Having one of the largest in Russia (and perhaps not only) experience in the follow-up of such patients, the team of the authors will undoubtedly continue their research. We sincerely wish them success.

\section{REFERENCES}

1. Artemev A.A., Brizhan L.K., Davydov D.V., Bytdaev Z.M., Kashoob A.M., Shipulin A.A., Gululyan G.G. Ulyanchenko I.N. Aesthetic surgery of the lower limbs in current orthopedic practice. Genij Ortopedii, 2021, vol. 27, no 1, pp. 59-67. DOI 10.18019/1028-021-27-1-59-67.

2. Feldman D.S., Madan S.S., Koval K.J., van Bosse H.J., Bazzi J., Lehman W.B. Correction of tibia vara with six-axis deformity analysis and the Taylor Spatial Frame. J. Pediatr. Orthop., 2003, vol. 23, no. 3, pp. 387-391.

3. Paley D. Principles of deformity correction. Berlin, Heidelberg, Springer-Verlag, 2002, 806 p. DOI: 10.1007/978-3-642-59373-4.

4. Rozbruch S.R., Ilizarov S. Limb Lengthening and Reconstruction Surgery. $1^{\text {st }}$ Ed. CRC Press, 2006, 696 p.

5. Rozbruch S.R., Hamdy R.C., editors. Limb Lengthening and Reconstruction Surgery Case Atlas. Switzerland, Springer International Publishing, $2015,886 \mathrm{p}$.

6. Whitaker A.T., Gesheff M.G., Jauregui J.J., Herzenberg J.E. Comparison of PACS and Bone Ninja mobile application for assessment of lower extremity limb length discrepancy and alignment. J. Child. Orthop., 2016, vol. 10, no. 5, pp. 439-443. DOI: 10.1007/s11832-016-0761-5.

7. Marker N.A. Vybor taktiki i rezultata ortopedicheskoi korrektsii goleni pri kosmeticheskoi deformatsii. Avtoref. diss. ... kand. med. nauk [Choice of tactics and result of the leg orthopedic correction for cosmetic deformity. Cand. med. sci. diss. abstr.]. Novosibirsk, 2009, 35 p. (in Russian) Available at: http://medical-diss.com/docreader/288249/a?\#?page=1 (accessed 31.03.2021).

8. Artemev A.A., editor. Esteticheskaia i rekonstruktivnaia khirurgiia nizhnikh konechnostei [Aesthetic and reconstructive surgery of the lower limbs]. M., GEOTAR-Media, 2008, 248 p. (in Russian)

9. Standard Sh.C., Herzenberg J.E., Conway J.D., Siddiqui N.A., McClure Ph.K. The Art of Limb Alignment. $3^{\text {rd }}$ Ed. Baltimore, 2019,236 p.

10. Koroliuk V.S., Portenko N.I., Skorokhod A.V., Turbin A.F. Spravochnik po teorii veroiatnostei i matematicheskoi statistike [Handbook of Probability Theory and Mathematical Statistics]. M., Nauka, 1985, 640 s. (in Russian)

11. Miniaci A., Ballmer F.T., Ballmer P.M., Jakob R.P. Proximal tibial osteotomy. A new fixation device. Clin. Orthop. Relat. Res., 1989, no. 246, pp. 250-259.

12. Solomin L.N., Shchepkina E.A., Kulesh P.N., Korchagin K.L., Lozdovskii A.A., Skomoroshko P.V., comp. Opredelenie referentnykh linii i uglov dlinnykh trubchatykh kostei: posobie dlia vrachei [Determination of reference lines and angles of long tubular bones: a guide for physicians]. SPb., Vreden RNIITO, 2012, 48 p. (in Russian). Available at: http://library.rniito.org/download/manuals/Opredelenie_referentnykh_liniy.pdf (accessed 31.03.2021).

13. Coventry M.B., Ilstrup D.M., Wallrichs S.L. Proximal tibial osteotomy. A critical long-term study of eighty-seven cases. J. Bone Joint Surg. Am., 1993, vol. 75, no. 2, pp. 196-201. DOI: 10.2106/00004623-199302000-00006. 
14. Fujisawa Y., Masuhara K., Shiomi S. The effect of high tibial osteotomy on osteoarthritis of the knee. An arthroscopic study of 54 knee joints. Orthop. Clin. Noth Am., 1979, vol. 10, no. 3, pp. 585-608.

15. Lobenhoffer P., Agneskirchner J.D., Gala M. Kniegelenknahe Osteotomien [Osteotomy in the region near the knee]. Thieme, 2007,161 p. (in German)

16. Solomin L.N., Chugaev D.V., Filippova A.V., Kulesh P.N. High Tibial Osteotomy for Genu Varum in Adults: Do Proprietary Implants Limit the Quality of Correction? Strategies Trauma Limb Reconstr., 2020, vol. 15, no. 1, pp. 13-22. Available at: https://www.stlrjournal.com/doi/STLR/ pdf/10.5005/jp-journals-10080-1449 (accessed 31.03.2021).

17. Catagni M., Guerreschi F., Lovisetti L., Tsibidakis H. Pelvic Support Osteotomy (PSO): Indications, Limits and Complications In: Kocaoğlu M., Tsuchiya H., Eralp L. Advanced Techniques in Limb Reconstruction Surgery. ${ }^{\text {st }}$ Ed. Berlin, Heidelberg, Springer-Verlag, 2015, pp. 433459. DOI: 10.1007/978-3-642-55026-3.

18. El-Mowafi H. Outcome of pelvic support osteotomy with the Ilizarov method in the treatment of the unstable hip joint. Acta Orthop. Belg., 2005, vol. 71, no. 6, pp. 686-691.

19. Inan M., Bowen R.J. A pelvic support osteotomy and femoral lengthening with monolateral fixator. Clin. Orthop. Relat. Res., 2005, vol. 440, pp. 192-198. DOI: 10.1097/01.blo.0000180602.00487.47.

20. Kocaoğlu M, Eralp L, Sen C, Dinçyürek H. The Ilizarov hip reconstruction osteotomy for hip dislocation: outcome after 4-7 years in 14 young patients. Acta Orthop. Scand., 2002, vol. 73, no. 4, pp. 432-438. DOI: 10.1080/00016470216308.

The article was submitted 16.04.2021; approved after reviewing 26.07.2020; accepted for publication 23.08.2021.

\section{Information about authors:}

1. Pavel N. Kulesh - Candidate of Medical Sciences, kulesh_pavel@mail.ru;

2. Leonid N. Solomin - Doctor of Medical Sciences, Professor, solomin.leonid@gmail.com. 